\title{
Digital Journalism
}

\section{Newsletters and the Return of Epistolarity in Digital Media}

\section{Clara Almeida Santos \& Ana Teresa Peixinho}

To cite this article: Clara Almeida Santos \& Ana Teresa Peixinho (2016): Newsletters and the Return of Epistolarity in Digital Media, Digital Journalism

To link to this article: http://dx.doi.org/10.1080/21670811.2016.1196591

曲 Published online: 05 Jul 2016.

Submit your article to this journal 주

Q View related articles $\longleftarrow$

View Crossmark data ¿ 


\title{
NEWSLETTERS AND THE RETURN OF EPISTOLARITY IN DIGITAL MEDIA The case of the Portuguese online newspaper Observador
}

\author{
Clara Almeida Santos and Ana Teresa Peixinho
}

\begin{abstract}
This article aims to analyse a new Portuguese online newspaper-Observador-in order to understand changes in the media, focusing on two main aspects: first, new narrative forms; and second, the ways in which these new forms relate to readers. This online news project was launched in Portugal in May 2014, with a strong professional structure, led by journalists who are highly acknowledged professionals in the Portuguese media. Before its launch, Observador announced: "We are digital natives and we will be doing the journalism of today." We argue that contemporary journalism recycles old traditions from the early days of journalism, cultivating the relationship of proximity provided by epistolarity, and reinventing agendasetting practices as well as the gatekeeping function.
\end{abstract}

KEYWORDS digital journalism; digital newsletters; epistolarity; gatekeeping; hypertext; multimedia

\section{Introduction}

Since the advent of Web 2.0, journalism and media in general have undergone rapid and profound changes: professional, organisational, rhetorical-discursive-hence, communication changes. This article analyses a relatively new Portuguese online newspaper-Observador-in order to understand some of these changes, focusing on two particular aspects: first, new narrative forms; and second, the ways in which these forms relate to readers.

This Web-only news project was founded in Portugal in May 2014, with a solid professional structure, led by nationally recognised journalists. It represented a pivotal moment, the point where online journalism reaches its ultimate state, as theorised by Cabrera (2000), while simultaneously hoping it will prove to be a sustainable business model. Even before its release, Observador announced: "We are digital natives and we will be doing the journalism of today."

This statement of intent is simultaneously a promise, a commitment, a pact with the audience, and a promotional slogan. It comprises a set of assumptions that will be discussed in this article, starting with its seeming paradox. What does "journalism of today $^{\prime \prime}$ mean? Is journalism not necessarily an activity anchored in its time? Is the 
Observador only a journalistic project? We will seek to answer these questions, starting with an analysis of the Observador newsletters, both as a journalistic genre and as metaphors for the new ways of conceiving the media.

\section{A Brief Characterisation of Observador}

Observador's editorial policy ${ }^{2}$ stresses its ambition to become a recognised reference national newspaper and highlights its exclusively digital nature. The newspaper is guided by 11 principles that clearly express its commitment to the general principles of most journalistic codes of ethics. Among others, it undertakes to pursue three innovative goals, breaking new ground in the Portuguese media landscape:

Observador aims to contribute to an informed and intervening public opinion. It values controversy, as well as honest and straightforward discussion.

Observador will look for attractive and relevant ways of presenting information, but will reject sensationalism.

Observador will be at the forefront of technological and relational changes, always seeking innovation and promoting interaction with its readers.

These three goals define a new position in the public space of the Portuguese media: on one hand, enhancing debate as a contribution towards strengthening public discussion; on the other hand, promoting innovation, at the level of both form and content, in order to offer the public new, attractive forms of presenting content, which includes the use of new communication technologies with a strong relational and intersubjective component. There is little tradition of exclusively digital newspapers in Portugal, with only a few local or thematic titles. Observador has described itself from the outset as a purely digital newspaper and as being national in scope. Its ambition is to be recognised as an online reference newspaper and its semiotic nature is designed for the Web and available related technologies.

This ambition is announced in the newspaper's inaugural editorial:

Observador is an online newspaper. It is not just a newspaper in a digital format, or a digital version of a traditional mass medium: it is a newspaper of the internet era that is aware of the new forms of accessing information and attempts to respond to them ... It is also a newspaper where journalists interact with their readers, where attention is paid to what they are looking for, their suggestions and their opinions, incorporating their inputs and contributions amicably, and seeing them as members of a large community, the Observador community. ${ }^{3}$

These statements are in line with the ways of practising the "journalism of today", which entails establishing a closer relationship with the readers (or should we say with the "consumers"?). One example of how to implement this approach is the creation of routines that engage the audience, such as daily newsletters distributed at set hours, with titles referring to their respective content in such a way as to grab the readers' attention. The Explicadores (Explainers) feature aptly illustrates this relational performance. Explicadores are shaped as small tutorials that explain a specific subject which needs to be summarised because it has some degree of complexity or is somewhat extensive. These communicative, and therefore, narrative forms are deeply marked by 
interpersonal relationship-building dynamics. Observador sees itself as "someone on the side-lines", someone who is defined by a name, or a brand, that is both a noun and an adjective.

\section{Observador in Context: A Pivotal Moment in Portuguese Digital Journalism}

Observador exemplifies the fourth stage of online newspapers development, reflecting the classification established by Cabrera González (2000). ${ }^{4}$ The author identifies four models of online newspapers, corresponding to the development of online journalism: ${ }^{5}$ facsimile editions, i.e. a simple reproduction of pages of the printed version of a hard-copy newspaper; the adapted model, which creates a specific layout for the online environment, with some integration of hypertext, though with the same content as the printed versions; the digital model, which takes advantage of some digital possibilities, with texts designed for online consumption and with a degree of interactivity, mainly expressed through comments and feedback; finally, the multimedia model, which fully explores the distinctive features of digital journalism, namely interactivity, hypertextuality, and multimediality.

The first 15 years of the history of online journalism in Portugal (1995-2010), summarised by Hélder Bastos (2010), were principally characterised by the use of the adapted model as well as by the emergence, in the mid-1990s, of sites belonging to the general daily newspapers, with little more than "dumped content"-shovelwarewhich Bastos describes as sometimes having "unbearably heavy pages, adorned with painful frames" (Bastos 2010, 3). At the turn of the century, after a time of unlimited faith in the possibilities of internet business, there was a very significant investment in news sites; matched by great expectations for the success of business models (though these would prove quite fragile). At this stage, the digital model was dominant, with formats and contents beginning to respond to new forms of production and new consumption possibilities, with a special focus on interactivity and multimediality. An example of this development is the emergence of infographics as a journalistic genre. ${ }^{6}$ This is then followed by a period of stagnation due to an inability to find a viable business model, and the investment that had been made was drastically reduced. This moment coincides, internationally, with the so-called bursting of the dotcom bubble. This stagnation in the development of online newspapers in Portugal fundamentally affects legacy media. In new projects that had emerged before the bubble burst, the situation was much more dramatic, with some business initiatives going bankrupt even before they were launched publicly, which obviously had serious social consequences. ${ }^{7}$ With digital convergence becoming a reality, the online journalism panorama necessarily underwent significant changes. Convergence is, in fact, according to Deuze (1999), the key feature of online journalism, requiring that all the eligible formats for the construction of journalistic narratives be explored.

Until recently, authors who have described the Portuguese digital media context (e.g. Bastos 2010; Canavilhas 2006) mention a moment of impasse in which a truly multimedia model was not achieved. The new features introduced by Observador can be considered a pivotal change. Multimediality and hypertextuality have been explored in several ways in Portuguese digital media. However, Observador was a true pioneer as 
concerns using a combination of hypertext and interactivity in its search for a new relationship of proximity with the audience. Acknowledging the importance of the community and its presence has indeed been a decisive factor in most recent experiences in digital journalism.

A detailed study of the development and transformation of journalistic narratives in Portuguese media has not yet been conducted, although it certainly is key to understanding the ways that journalism has been envisioned and engaged in. Narrative has always been the textual superstructure best adapted to journalism. It is, however, no less true that the concept of narrative has changed over time, and those changes have been quite remarkable in the last decade. Some authors have shown how the structure of news, a relatively fixed narrative style form since the early twentieth century, has changed with the advent of the digital age, reconfiguring the traditional superstructure of the inverted pyramid into a more complex one, which Portuguese author João Canavilhas calls the "tumbled pyramid". With his analysis of hypertextual news, the author shows how the traditional superstructure of news-the inverted pyramid-has changed with digital media. The structure of online news, Canavilhas (2006) argues, is based on the criterion of depth instead of the traditional criterion of information relevance. In both printed and digital news, the first information is considered the most important one, contrary to traditional storytelling: as J. Miller points out, "traditional storytelling is linear. The inverted pyramid structure is taught to journalists for a reason: people want to understand the story immediately" (Black and Elder 1997, 106). By comparing printed and digital news, it becomes clear that the focus shifts from the journalist's point of view to a more audience-centred approach. Printed journalism shares the linear or syntagmatic experience of traditional storytelling. Digital journalism, however, provides the opportunity for the audience to make decisions, especially through hypertextuality, which enables readers to amplify their understanding of the subject-matter, or the narrative, outside the medium where their reading process began.

The absolute dominance of the hypertext narrative, chiefly built as an inter-text with a multimedia logic, has transformed our relationship with reality in the last 10 years. Identifying the disruptive role of the new media, Marc Lits stresses the urgency of new models of analysis, proposes the creation of a "media hyper-narrative" for the analysis of such complex objects as today's media stories, and discusses sensationalism and the weakening of the boundaries between reality and virtual worlds (Lits 2008).

These changes were brought about chiefly by the advent of Web 2.0, particularly concerning the communication structure of texts and their semiotically expressive composition. As regards text composition, that which in traditional journalism was mainly written text has been replaced by a semiotic composite of sound and moving pictures: the plurality of languages, characteristic of a hypertext, is the hallmark of the new online news stories, materialising the ideal of textuality established by Roland Barthes back in the 1960 s. $^{8}$

Barthes' description of a text as a non-hierarchical network organisation, where the structural rigidity of meaning is replaced by a constellation of signifiers, in which the text limits are blurred, losing their sharpness and inviting a multitude of readings, corresponds to today's reality. It is the reality of the digital hypertext, ${ }^{9}$ which has undergone an important transformation during the first decade of the twenty-first century. The change was due to three Web phenomena: the emergence and proliferation of 
new platforms, a preference for microcontent, ${ }^{10}$ and the new "social architecture", ${ }^{11}$ as Bryan Alexander $(2011,29)$ calls it.

Jan van Dijk's work on the information society very clearly defines the main features of a new medium of the present as characterised by convergence, interactivity, and the use of digital codes, combining new communication models: ${ }^{12}$

The new media are defined by all three characteristics simultaneously: they are media which are both integrated and interactive and also use digital code at the turn of the 20th and 21 st centuries. It follows that their most common alternative names are multimedia, interactive media and digital media. Using this definition it is easy to identify media as old or new. (Van Dijk 2005, 9)

Using the case of Observador, we will seek to explain how the transition to new narrative languages entails a different way of conceiving journalism and its practices.

\section{From Classical to Digital Epistolarity}

The change from classical to digital epistolarity brought about profound changes in newspaper communication, especially concerning its nature as an informational object, recovering some old communication techniques that are historically rooted in the nineteenth-century epistolary tradition. Although this comparison may seem somewhat anachronistic, an analysis of how interactivity is enhanced in online journalism easily uncovers the presence of speech properties and textual formats rooted in older genres.

In fact, the most famous Portuguese newspapers of the nineteenth century are mainly the result of epistolary contributions: open letters written by intellectuals and men of letters aiming to influence the public space and triggering debate and controversy over a number of themes. The use of the epistolary mode as a form of public intervention occurs frequently also in other political contexts in European countries. During the eighteenth century, the letter format was used by French writers of the Enlightenment period and, according to Diaz $(2002,43)$, it was an essential element in every important debate of the century, where it became an indispensable tool for formal epistemological thought. The use of the open letter was very frequent in the nineteenth century also, especially among celebrated writers such as Emile Zola, who in 1898 published his famous letter "J'accuse", formally addressed to the French President Felix Faure, although really addressed to all French people. Similarly, in The Letters of the Republic, Michael Warner shows how important the role of the press was in the consolidation of the North American public sphere during the eighteenth century. The author emphasises the significant space occupied by the open letter in the public debate over the legislative and political questions of the time (Warner 1995).

In the nineteenth century, as a consequence of the development and massification of journalism in Portugal, resorting to this type of texts becomes an increasing practice, and newspapers become public arenas of debate and discussion where the exchange of letters is crucial: letters from correspondents, open letters, epistolary editorials, letters from the readers, among others.

According to Charles Bazerman, the epistolary form has a very important genetic dimension. It can be understood as a "transactional form" that triggers the emergence 
of genres which share the same communicational structure and are grounded in the same social situation. One of the genres mentioned by Bazerman is precisely the newspaper.

The letter in several instances appears to have served as a transitional form to allow genres to emerge with some sense of defined communicative task with some moorings of social relationship. At least three major types of writing that flourished in print culture seem to have some connection with letter correspondence: newspapers, scientific journals, and the novel. (Bazerman 1999, 23)

At the beginning of the twentieth century, Gabriel Tarde (1989) wrote a seminal text on the creation of the public space and the formation of public opinion. Explaining the importance of journalism in the formation of public opinion, the sociologist sees the newspaper as a public letter, with important functions in modelling the audience and providing a new way for sharing opinions. Discussing the pre-industrial period of the press, Habermas stresses how critically important private letters were in the emergence of what he calls the "journalistic trade": "Arising from the system of private letters and sponsored by it for a long time, the journalistic trade was just beginning, organised like any small craft industry" (Habermas 2002, 209).

The idea of a journal as an open discussion forum is still valid today, as is confirmed by a number of studies devoted to public participation through readers' letters. In an article about the importance of the Letters to the Editor section in the American press, Karin Wahl-Jorgensen writes:

the letters page is an oasis of public discussion left untouched by the cynicism and faltering participation that plagues the larger society. It gives citizens "access to the newspaper" and takes the "community's heartbeat", it is "the people's pulpit" and "an essential ingredient to public access. (Wahl-Jorgensen 2002, 122)

If in the nineteenth- and early twentieth-century press the reader's voice emerged basically within the space occupied by the Readers' Letters (Peixinho 2011; Torres 2010), the social architecture of the new media now allow for greater interactivity and provide easier access to public participation. Spaces of opinion are present in all online newspapers, as well as in radio and television programmes in which the viewer/listener can participate and intervene, a practice that simulates dialogue in its interpersonal communication dimension. Thus, the new journalistic narratives recover many of the communication features of a public space, which, as initially described by Habermas, was dominated by individuals with the same access and right to participate, exchanging messages and publicising opinions. ${ }^{13}$ However, the issue of interactivity should be looked into at two different levels: at the level of the medium, with its technical capabilities allowing for a higher or lower degree of interactivity; and at the textual level, since speech itself is inherently interactive. ${ }^{14}$

The Observador newsletters translate the transformation from atoms into bits described by Nicholas Negroponte in Being Digital. Being digital is, after all, a result of this transformation. As the author wrote as far back as 1995:

As one industry after another looks at itself in the mirror and asks about its future in a digital world, that future is driven almost 100 per cent by the ability of that company's product or services to be rendered in digital form. (Negroponte 1995, 12) 
The Observador represents this passage: the basic characteristics of epistolarity remain but they are now expanded through the use of the opportunities created by digital distribution; it also has significant benefits for the sender, i.e. Observador: on the one hand, production costs are considerably lower, on the other, the newspaper gains a clearer perception of its readers'/users' profile, providing customised choices that correspond to their preferences, as will be demonstrated below.

As predicted by Negroponte (1995), the media of today are, by and large, bits: the mix of bits that generates multimediality and the exponential creation of bits that refer to other bits and organise them. These are, in fact, the main characteristics of the newsletter "transfiguration". Newsletters might be seen as bits organising other bits: they do not provide "new" bits of information, they organise information that is already available someplace else (within the newspaper or outside it, as we shall describe). Furthermore, newsletters change: the subject of our analysis has changed since our data were collected. At the time, Observador offered four newsletters. Now, only a few months later, there are five newsletters available for subscription: three remain the same, one has disappeared, and two new ones were added. The bits generated by the newspaper's analytics probably generated the new bits.

\section{The Observador Newsletters}

As explained above, when our data were collected, Observador was providing four daily newsletters for those wishing to subscribe. A link labelled "Newsletters" can be found on the newspaper's homepage, redirecting to a submission page where the user can select one or more newsletters.

The submission routine seems to respond to four public needs, segmented by time parameters. ${ }^{15}$ The first newsletter of the day, $360^{\circ}$, is sent out at $9.00 \mathrm{am}$, and is signed by David Dinis, the first chief editor of Observador. ${ }^{16}$

Another newsletter is sent out at $12.00 \mathrm{pm}-$ Meu Observador (My Observer)which, as the name suggests, is personalised. Meu Observador allows the user to select topics (from a very long list), online newspaper authors, and programmes (videos) to be followed. The newsletter is built on the basis of that choice, with links as they appear on that particular day. Receiving this newsletter requires a social network registration (Facebook or Google Plus).

Hora de Fecho (Closing Time) is the title of the $5.00 \mathrm{pm}$ newsletter, marking, as its name indicates, the closing hour of a newspaper edition, as if it were being issued from a traditional newsroom. This newsletter is not signed and includes a synthesis under the heading "Top News of the Day", followed by the greeting "Good evening!", with a photograph beneath it. This is followed by a news selection, usually 10 , invariably displayed in the following format: a short pre-title (which establishes the topic and can be repeated at the end), a title (which functions as a link to the article on the Observador website), and a three-line standfirst. Then there are five opinion articles, whose titles function as links to the full articles, followed by the authors' names and a short threeline summary.

Macroscópio (Macroscope) has a similar structure to the $360^{\circ}$ newsletter, with the title followed by the author's signature, José Manuel Fernandes, Publisher, and then the greeting, "Good Evening". It is built as an analytical text, an author's digest of the day's 
affairs with links to Observador as well as to other sources. There is also an ending sentence, not always the same, but often wishing "enjoy your reading" or expressing a greeting such as "see you tomorrow". Differently from 360", Macroscópio is more similar to Hora de Fecho as concerns page syntax and displays a photograph before the body of the text.

$360^{\circ}$, Hora de Fecho, and Macroscópio are sent out only on weekdays. Although they are announced on the Observador website subscription page as regularly issued at set hours-9.00 am, $5.00 \mathrm{pm}$, and $8.00 \mathrm{pm}$, respectively-there is no mechanised process that ensures that they are received exactly at those hours. $360^{\circ}$ normally arrives 20 or 30 minutes after $9.00 \mathrm{am}$, and Macroscópio is usually sent out 20 or 30 minutes before $8.00 \mathrm{pm}$. Curiously, Hora de Fecho, which is the only newsletter not signed by an author, is the one that usually reaches its readers exactly at the appointed time (with residual exceptions in the sample considered). ${ }^{17}$

This ritualisation of the newspaper's contact with its readers/users is very interesting: on one hand, it is a strategy that increases reading routines/consumption, which is key for establishing reader loyalty; on the other hand, it reminds the readers of its presence throughout their day, following their daily lives, caring for their daily rhythm, and attending to their interests and needs. It is a simulacrum of a family relationship, much in the way the old nineteenth-century correspondents used to do with their letters: newsletters are the strongest link between newspapers and citizens.

\section{Newsletters Analysis}

We have decided to focus our analysis on the two newsletters with more authored content, $360^{\circ}$ and Macroscópio, due to the significant difference of Meu Observador, which has a high level of customisation, and the fact that Hora de Fecho is built from the highlights of the day and does not resort to epistolary techniques as extensively as the others. The analysis will be mainly textual and qualitative, as this approach appears to be the most useful for the identification of textual changes aimed at building an interactive and dialogical speech. However, we will also use some relevant quantitative data in our analysis of this journalistic format. When addressing our corpus, we have considered the following four variables: (1) marks of epistolarity, (2) enunciation, (3) textual structures, and (4) intertextual links. The first of these variables will help clarify to what extent the dialogical construction of newsletters is processed by reusing discursive strategies that are characteristic of the epistolary mode (Altman 1982; Kauffman 1992), explaining how a new genre feeds on the recycling of old genres. Thus, the beginning and end of the texts will be analysed, paying special attention to the presence of specific marks of an epistolary protocol (introductory formula and signatures). The enunciation variable, as Benveniste defined $\mathrm{it}^{18}{ }^{18}$ will give us access to the enunciative configuration of the newsletters and help us define the degree of objectivity of the texts. The textual structures variable will help identify the predominant discursive modes, through an analysis of the letters' superstructure: narrative, argumentative, or mixed. Finally, the intertextual connections must also be considered because they emphasise the hypertext structure. Discriminating these variables only makes sense as a methodological strategy, because the end result of the analysis shows that these different marks intersect in the texts and exposes their subsidiarity, which 
contributes to the goals of creating proximity to the reader, proposing reading as a pre-mediated reality, working as an information cluster in a time of paradoxes where information is abundant and available in such excess that it is essential for it to be organised by someone who has the legitimacy to do it.

The corpus of this analysis is an exploratory sample of 16 newsletters: eight from $360^{\circ}$ and eight from Macroscópio. Since the newsletters began to be sent out when Observador was first issued, in May 2014, the total number of newsletters after a year was 520. We chose to use a stratified random sampling process by selecting two newsletters per month (one from $360^{\circ}$ and one from Macroscópio) from September 2014 to April $2015^{19}$ (see Table 1).

As concerns the first category of analysis-enunciation-it became apparent that $360^{\circ}$ displays marks of subjectivity, manifested at two different levels. At a macro-level, the selection of news and the press summary result from a screening, performed by the author, that dictates what should be retained as relevant; at a micro-level, numerous speech modalities can be detected, especially of an evaluative and commissive nature, some of which may result from the epistolary focus on discourse, namely its conversational tone: an abundance of personal marks, and the explicit presence of the first-person plural in the speech are clear signs of that. As in a personal letter, the enunciator takes the position of someone trying to make up for the insufficiency of the enunciative framework, creating bonds with the readers. Written in the first person, Macroscópio is clearly an opinion newsletter that offers a personal reading of public space events and texts. Although it also builds bridges with the readers, it does so while using a more common and less informal tone, inviting them to follow an argumentative reasoning.

From the point of view of textual structure, both newsletters have differences: while $360^{\circ}$ is structured like a typical letter, as we will demonstrate, Macroscópio is structured more like an op-ed. Considering the two main superstructures that dominate

TABLE 1

Dates and hours of the newsletters' reception in the analysed sample

\begin{tabular}{lll}
\hline Newsletter & Date & Sending time \\
\hline $360^{\circ}$ & 9 September 2014 & $9: 08 \mathrm{am}$ \\
$360^{\circ}$ & 2 October 2014 & $9: 15 \mathrm{am}$ \\
$360^{\circ}$ & 21 November 2014 & $8: 54 \mathrm{am}$ \\
$360^{\circ}$ & 12 December 2014 & $9: 14 \mathrm{am}$ \\
$360^{\circ}$ & 14 January 2015 & $9: 25 \mathrm{am}$ \\
$360^{\circ}$ & 2 February 2015 & $9: 07 \mathrm{am}$ \\
$360^{\circ}$ & 31 March 2015 & $9: 26 \mathrm{am}$ \\
$360^{\circ}$ & 6 April 2015 & $9: 18 \mathrm{am}$ \\
Macroscópio & 8 September 2014 & $7: 17 \mathrm{pm}$ \\
Macroscópio & 9 October 2014 & $8: 29 \mathrm{pm}$ \\
Macroscópio & 24 November 2014 & $7: 40 \mathrm{pm}$ \\
Macroscópio & 16 December 2014 & $8: 03 \mathrm{pm}$ \\
Macroscópio & 21 January 2015 & $8: 31 \mathrm{pm}$ \\
Macroscópio & 9 February 2015 & $8: 08 \mathrm{pm}$ \\
Macroscópio & 30 March 2015 & $8: 47 \mathrm{pm}$ \\
Macroscópio & 7 April 2015 & $6: 06 \mathrm{pm}$ \\
\hline
\end{tabular}


textuality, it is also important to note that $360^{\circ}$ tends to be narrative, while Macroscópio has more argumentative dynamics. Among the newsletters by David Dinis which have been analysed, number eight builds a metanarrative, composed of micro-narratives resulting from the selection of events mediated by both the national and the international media. As a press correspondent, the author, who is invested with a legitimacy that originates in his auctoritas in the journal structure, aims to update the reader on key current events, whether they be hard news or soft news. The newsletter also provides a set of brief summaries of more complex stories, selected from a wide range of media, always starting with political and economic news, and ending with the softest fait divers. Permeating these stories, his voice guides the readers and creates ties that enable the journalist to create and sustain a long-term epistolary relationship with his readers. Macroscópio does not have this dispersive, plural structure, focusing instead on a smaller number of issues about which the author, José Manuel Fernandes, takes a stand and offers a critical reading. As in an op-ed, the author shares his point of view, trying to gather the consensus of his audience with various arguments, and filtering the topics.

In the analysis of the epistolary marks present in the first newsletter of the day, $360^{\circ}$, what immediately stands out is the greeting located below the sender's signature: the reader is confronted with an effusive "Good morning!" This first newsletter of the day is a selection of highlights of what has happened since the previous day, with news or issues that remain on the agenda, in the opinion of the journalist who selects them. These are organised in four sections, separated by titles: Enquanto dormia (While you were sleeping), Informação relevante (Relevant information), Os nossos especiais (Our specials), and Notícias surpreendentes (Surprising news). The newsletter ends with a farewell, "Até já!" (See you soon), before the promotional component that aims to encourage readers to share the newsletter on social networks, to read the Observador, and to subscribe to other newsletters. There is a fixed structure that opens with the title of the letter, the signature [including the word "Director" (Editor), which is the legitimating authority mark], followed by paragraphs-between 13 and 26, in the sample analysed-separated into three themes, and ending with the farewell greeting, whose deictic and colloquial formulation indicates proximity.

In terms of marks of epistolarity, Macroscópio follows the $360^{\circ}$ model, as has already been mentioned. The title is followed by the author's name (José Manuel Fernandes) and the indication of the position he holds in the newspaper (editor), with a greeting formula ["Boa noite!" (Good evening!)] ending this header. The structure of the newsletter, however, is not divided into sections, but rather proposes one or two topics selected by the author, as explained above. The ending formula is differently written on each occasion, displaying a common mark: the wishes of "bom descanso e boas leituras" (good rest and good reads) expressed either in this format or using other similar formulae.

In $360^{\circ}$, each paragraph corresponds roughly to a hot topic. The first section of the newsletter is titled, as already mentioned, Enquanto dormia (While you were sleeping), and focuses especially on international news. Therefore, it is not surprising that the links suggested lead to foreign media. Although this seems to be the rule, it can be observed that, even in this section, the links often refer to Observador itself. Informação relevante (Relevant information) includes news that is on the agenda: at this point one finds more links to national media. The situation is reversed in the next section; 
Os nossos especiais (Our specials), as the name implies, focuses mainly on the work developed by the Observador editorial team. Notícias surpreendentes (Surprising news), the last one, is a kind of faits divers collection, referring again mainly to Observador articles.

The proliferation of links in each paragraph is quite evident in $360^{\circ}$ : from the example of the newsletters with less and with more links within the analysed sample, we were able to observe that the $360^{\circ}$ issue with 21 links includes 13 paragraphs and the one with 37 links has 27 paragraphs. From this we may conclude that links are undoubtedly the principal raw material of these digital epistolary communication objects. In analysing the nature of these links, or when trying to figure out where the author of the newsletter wants to lead the reader to, we were able to conclude that the main reason behind the use of this strategy may be self-reference [which is understandable in the light of cross-promotional marketing: there are on average more than 27 links per $360^{\circ}$ issue; of these, 73.8 per cent are "internal", 21.7 are links to other Portuguese media (especially newspapers), and only 4.5 to international media].

In the case of Macroscópio, the paragraphs are fewer, ranging from 11 to 24 in number, longer, and with fewer links (an average of 15.6 links in each newsletter), most usually 13 links (identified in five of the eight Macroscópio issues analysed). With the average number of paragraphs standing at 17.4, it appears that there are 1.1 links per paragraph in these newsletters. The most common type of link redirects readers to national media (43 occurrences). The references to Observador and the links to foreign media have the same number of occurrences: 41 .

It thus becomes clear that $360^{\circ}$ is the newsletter with more links, as well as the most diversified and eclectic, especially when one considers the Portuguese media, from traditional, hard-copy newspapers to blogs; it has international links, mainly leading to reference publications, especially the New Yorker, the Financial Times, the Wall Street Journal, as well as to some blogs.

This brief analysis of the main characteristics of some of the newsletters issued by Observador clearly shows that they explicitly promote one another. At the end of each of them one can find an invitation to subscribe to the other existing newsletters ["Subscreva as nossas Newsletters" (Subscribe to our Newsletters)]. However, this "call to action" is not restricted to a self-promotion strategy: each newsletter contains a link to the Observador website ["Leia as últimas em observador.pt" (Read the latest news on observador.pt)], and also relies on the inclusion of links that invite readers to share its content on social networks and through email ["mais pessoas vão gostar da [nome da newsletter]. Partilhe: no Facebook no Twiter por e-mail" (more people will like [name of the newsletter]. Share: on Facebook on Twitter by e-mail)].

Regardless of what has been said concerning the self-promotion strategy carried out by Observador, one of the assets of these newsletters is the fact that they provide access to other media, in the case of Macroscópio and $360^{\circ} .{ }^{20}$ In the former, the links to other contexts of information focusing on publications across the border is the rule, as was stated above. The Portuguese media are also abundantly referenced in this newsletter, which serves also as a kind of thematic press review (although often looking into more than one issue) and encourages the development of the topics in alternative, external media. $360^{\circ}$, on the other hand, frequently provides links to Observador, although it also quotes from and resends readers to other, mostly national, media. 
The authorial mark in these two newsletters is quite distinctive. When they reach the readers' mailboxes at a set hour (or nearly so), the emails they are attached to display the signature in the sender area: "David Dinis-Observador" in $360^{\circ}$ and "Observador, José Manuel Fernandes" in Macroscópio. According to Barthes, claiming authorship may be considered a function-sign of high semiotic value. Here, it also denotes the strategic statement of Observador as a brand. It further emphasises that same brand through the credibility afforded by the real people who sign and symbolically send the newsletters. This practice is particularly important at a time when, in terms of media consumption, brands seem to be fading out, as contents are disseminated by a number of different platforms, and, when they arrive at their destination, those contents have frequently lost their primary source along the way. As Thorson and Wells (2015) put it, media ecology is still dominated by the usual suspects, although journalism does not occupy the same place in media ecology, overrun as it is by news startups (a category in which Observador fits), social networks 15 platforms, browsers, or news aggregators. Supposedly, at least, as the authors maintain, since someone, somewhere is still producing content. Big media corporations are still the main suppliers, although the brand might be blurring away in an audience's perspective.

These are some of the singularities that differentiate the construction of the Observador newsletters from its information product counterparts found in foreign media. Newspapers from Le Monde group, such as Le Monde, Courrier International, and Le Monde Diplomatique, also offer the possibility of newsletter subscriptions from their digital editions. However, even if they offer their readers various types of newsletters, these are fundamentally, with one or two exceptions, thematic issues, featuring sports reviews, reviews of the main news on the front page, or lifestyle reviews. It is possible to receive a newsletter at specific times, with topical articles, though access to those contents requires a paid subscription. We believe that the Observador formula, where analysed content resulting from an author's selection is sent out for free at specific times of the day, is probably unique.

The analysis of these journalistic objects confirms the "second-hand" agenda theory. We share McCombs and Shaw's (1972) principle that the media partly determine public opinion, since they establish the subjects on which that opinion is built. We may therefore say that the Observador newsletters build an agenda on the basis of which they propose new readings or complementary and supplementary views. McCombs and Shaw postulated agenda-setting theory, according to which journalists were responsible for setting the public agenda. This view is closely linked to the traditional perspective of journalists as gatekeepers. These newsletters, however, challenge this perspective: the journalist-sender acts as a public space curator, rearranges it as he interprets the agenda, and puts his/her personal style at the service of that "proximity curatorship". The "curation of flows" is precisely one of the possible dimensions of the transition occurring in gatekeeping and brought about by digital challenges.

We could again mention Negroponte (1995) and his conclusions on the consequences of the digital age. Information about the information may be more valuable to the user than the information itself. This assertion, which is particularly acute at a time when the informational paradox is so present-with more and more information available and supposedly less ability to deal with it-may explain the success of a formula such as the Observador newsletters. 
According to audience data published on the Observador website, the number of visits to the newspaper between December 2014 and December 2015 increased by over 100 per cent $(15,286,675$ in December 2014; 32,437,874 in December 2015), with 51 per cent being made through mobile devices. The number of unique visitors/clicks in January 2016 was 3,229,940. The number of newsletter subscribers has also been increasing: in May 2014, when Observador first started, there were 14,992 subscribers; after eight months, the figure had risen to 96,393 . The number of subscribers in January 2016 was 201,263 . However, the data on the newsletter open rates point to a gradual drop: in January 2015, 36 per cent of people opened them but in January 2016 only 21 per cent did so.

\section{Conclusions}

It is, of course, impossible to know what the future of Observador will bring, and it seems premature to make predictions. However, according to our findings, this project launches a set of significantly innovative communication strategies in the Portuguese media panorama.

The innovative character of Observador is built primarily on two different levels: first, as a form of expression Observador is in fact a digital native, existing only as a product on the Web and defining itself as a brand at a time when brands are fading out. On the other hand, it is built as a means of communication. The online newspaper explores the great potential of interpersonal communication in order to produce a sense of proximity to its readers/consumers. As we have seen above, these two aspects have proved to be the main features of this new project, which focuses on close communication, values the reader, and sees the globalisation of information as an advantage rather than a threat. The newsletters analysed here are a clear example of that.

It also seems relevant to us that these "innovations", enhanced by networking and new technologies, are the result of an interesting dynamics of recycling of old traditions that can be found in the early days of the history of journalism, including the space occupied by opinion, the recovery of the relationship of proximity through epistolarity, the reinvention of agenda setting in the manner described above, and, above all, the reinvention of the gatekeeping function.

As concerns the hypothesis of a valuation of agenda setting, the analysis of the newsletters shows that special care is taken to highlight topical issues which, in the eyes of the authors (legitimised by their status of editors and publishers), deserve special attention from the public. This selection is no longer made from the event (as diegetic matter) as it is in traditional journalism, but rather from media narratives, and national and international stories selected on the basis of the commitments made in the Observador editorial statement: to contribute to an informed and involved public opinion, valuing controversy and open discussion. Thus, the newsletters' authors act as gatekeepers who propose a second-hand reading of the reality previously built by a multitude of media.

This method of journalism is definitely growing. Proof of this is seen in two events that occurred while this article was being written. The first: Expresso-the most important weekly Portuguese newspaper-and Diário Económico-a newspaper that has recently (March 2016) become digital-started to send out daily newsletters at a set hour. Expresso Curto (Short Expresso-also readable as short espresso) is served just 
before 9 am, and Económico à Uma (Económico at One) is sent out at lunchtime. Although this is not the occasion for examining these objects, it may be said that, although they are objectively different from the Observador newsletters, they pursue much the same goals.

The second event is the emergence, in March 2015, of advertising in the newsletters' headers. It is an undeniable evidence of the performance awareness of this format, which, we believe, can be seen as an icon of a new way of conceiving and "doing" the media today.

The famous Portuguese modernist artist Almada Negreiros claimed, in 1921, that "we do not belong to a word-inventing century. Words have already been invented. We belong to a century which reinvents words that have already been invented." Mutatis mutandis, almost a century later, we could say that this is the century of reinventing the journalistic genres that have already been invented.

\section{DISCLOSURE STATEMENT}

No potential conflict of interest was reported by the authors.

\section{NOTES}

1. Statement available on the Observador website before its launch, quoted by Público at http://www.publico.pt/politica/noticia/novo-jornal-digital-o-observador-lan cado-dia-19-1635262, accessed January 2015.

2. See http://observador.pt/estatuto-editorial/, accessed January 2015 and translated from Portuguese.

3. Text authored by José Manuel Fernandes, the newspaper's editor-in-chief, on 14 May 2014: http://observador.pt/explicadores/tudo-o-que-precisa-de-saber-sobreo-observador, accessed 16 January 2015.

4. The typology established by Cabrera in 2000 is still quite pertinent because it has been able to anticipate, in a visionary though very lucid way, what has actually happened and is still happening in the digital media world.

5. Since this is not the place to mention the discussion on the term used to define journalism on and for the internet, we choose the expression online journalism to describe the practice that aims to produce journalistic content for digital platforms.

6. Despite the scarce number of professionals dedicated to this genre in the newsrooms of that period, as pointed out by Ribeiro (2008).

7. That was, for example, the case with imaterial.tv, an online journalism site that ended without ever having been made available online. It had a writing team of 40 journalists who had worked for four months to prepare the project and who ended up being unemployed (according to a statement from the Portuguese Journalists Union available at http://www.jornalistas.eu/?n=165).

8. "In this ideal text, networks are many, in interaction, with none imposing itself on the others; this text is a galaxy of signifiers, not a structure of signifieds; It has no principle, but rather several access roads, none of which can qualify as 
principal; the codes it mobilises extend as far as the eye can reach; they are interminable...; the systems of meanings can be imposed on this absolutely plural text, but their number is never limited, since it is based on the infinity of language" (Barthes 1970, 11-12).

9. On hypertext, see Furtado (2000), Landow (1995), Pereira (2002), and Virgil (2007).

10. "Microcontent is often much smaller than Web sites in terms of the amount of storage that each chunk takes up: blog posts, wiki edits, YouTube comments, and Picasa images are usually only a few thousand bytes. Some types of microcontent, interestingly, can be quite large from a storage perspective but are so easily managed and self-contained as to fall into the microcontent category: for example, audio files (podcasts), pdf files to Slideshare, or video (for Web platforms such as YouTube)" (Alexander 2011, 30).

11. "Web 2.0 sites, in contrast, allow multiple channels of communication between site visitors, site creators, and other parties. They are fundamentally designed to encourage such connections through wiki editing, comment threads, media embedding, tagging, Facebook Liking, Digg and Reddit services, and more. A site's visitor can leave comments or add tags, or link to it from their own site. Other visitors can see these comments and other connections, like a party guest entering a room where a conversation is in full swing. Multiple users can build objects and collections together, from an iterated wiki page to a shared Flickr photo pool to a co-drawn Gliffy image" (Alexander 2011, 31).

12. See the Council of Europe report, published in 2009 (Jakubovicz 2009, 14ff).

13. For Habermas, the Enlightenment was a key period in the construction of the bourgeois public space, meant as "the sphere where private people meet as an audience" (Habermas 2002, 65). According to the author, the eighteenth century saw the birth of several cultural phenomena, including the emergence of numerous urban spaces, which facilitated the discussion of many public issues. Firstly, literary and cultural, but rapidly moving to the political: during the eighteenth century the cafés in France and England, the salons and the curious "ruelles", museums and theatres became socio-discursive spaces, true meeting points for sophisticated and educated people, where discussion and opinion sharing took place. They were bourgeois structures where groups of individuals engaged in discussions, criticism, and wrote about literature and culture. The weight of urban civilisation created "new institutions which, in their diversity, have the same social functions in England and in France: the coffee houses in their flowering period, between 1680 and 1730, and the salons, between the Regency and the Revolution" (Habermas 2002, 70).

14. On the typology of interactivity as an intellectual property, see Ryan (2001, 204-224).

15. Our analysis of the newsletters was based on a sample collected via an Observador subscription, between September 2014 and April 2015.

16. David Dinis ceased to be editor-in-chief in March 2016.

17. The two newsletters that were added after our collection of the corpus are weekly and thematic: Lifestyle and Startups (both titles originally in English).

18. Our reference is Benveniste's classification of statements, which distinguishes between discursive statements and historical statements; the former are marked 
by a particular pronoun and deictic structure, and tend to be more subjective (Benveniste 1978a, 1978b).

19. Although the Observador project started in May 2014, we found it preferable to collect our sample only from September on, because, in our opinion, only by then would the routine and format have been perfectly stabilised.

20. Although this is a characteristic of digital journalism, newsletters bring this evidence to a greater scale due to the ratio between text length and number of links (in March 2016, 38 million pages were already read, according to data provided by Observador on its website).

\section{REFERENCES}

Alexander, Bryan. 2011. The New Digital Storytelling. Creating Narratives with New Media. Oxford: Praeger.

Altman, Janet Gurkin. 1982. Epistolarity. Approaches to a Form. Columbus, GA: Ohio State University Press.

Barthes, Roland. 1970. S/Z. Paris: Seuil.

Bastos, Helder. 2010. "Ciberjornalismo: dos primórdios ao impasse [Ciberjournalism: from the beginnings to an impasse]." [In Portuguese]. http://www.bocc.ubi.pt/pag/bastoshelder-ciberjornalismo-dos-primordios-ao-impasse.pdf.

Bazerman, Charles. 1999. "Letters and social grounding of differentiated genres." In Letter writing as a social practice, edited by David Barton and Nigel Hall, 15-29. Amsterdam / Philadelphia: John Benjamins Publishing Company.

Benveniste, Emile. 1978a. "Da subjectividade na linguagem [Subjectivity in Language]". [In Portuguese]. In O Homem na Linguagem. Ensaios sobre a instituição do sujeito através da fala e da escrita, edited by Maria Alzira Seixo (dir.), 2nd ed., 57-65. Lisboa: Arcádia.

Benveniste, Emile. 1978b. "As relações de tempo no verbo francês [Relations of Tense in the French Verb]". [In Portuguese]. In O Homem na Linguagem. Ensaios sobre a instituição do sujeito através da fala e da escrita, edited by Maria Alzira Seixo (dir.), 2nd ed., 33-48. Lisboa: Arcádia.

Black, Roger, and Elder, Sean. 1997. Web Sites that Work. Prentice Hall: illustrated edition.

Cabrera, Maria Angeles. 2000. La prensa online: los periódicos en la WWW [Online Press: Newspaper in the WWW]. Barcelona: CIMS.

Canavilhas, João. 2006. "Webjornalismo: da pirâmide invertida à pirâmide deitada [Webjournalism: From the Inverted Pyramid to the Tumbled Pyramid]." [In Portuguese]. http://bocc.ubi.pt/pag/canavilhas-joao-webjornalismo-piramide-invertida.pdf.

Deuze, Mark. 1999. "Journalism and the Web: An Analysis of Skills and Standards in an Online Environment." Gazette 61 (5): 373-390.

Diaz, Brigitte. 2002. L'épistolaire ou la pensée nomade [Epistolarity or Nomad Thinking]. Paris: PUF.

Furtado, José Afonso. 2000. Os Livros e as Leituras-Novas Ecologias da Informação [Books and Reading-New Ecologies of Information]. Lisboa: Livros e Leituras.

Habermas, Jürgen. 2002. Historia y Crítica de la opinión pública. La transformación estructural de la vida pública [History and Critique of Public Opinion: The Structural Transformation of Public Life]. Madrid: Ediciones G. Gili.

Jakubovicz, Karol. 2009. A new notion of media? Strasbourg: Council of Europe. 
Kauffman, Linda S. 1992. Special Delivery. Epistolarity Modes in Modern Fiction. Chicago and London: The University of Chicago Press.

Landow, George. 1995. Hipertexto. La convergencia de la teoría crítica contemporánea y la tecnología [Hypertext: convergence between contemporary critical theroy and technology]. Barcelona: Paidós.

Lits, Marc. 2008. Du récit au récit médiatique [From Narrative to Media Narrative]. Bruxelles: De Boeck.

McCombs, Maxwell E., and Donald L. Shaw. 1972. "The Agenda-Setting Function of Mass Media." The Public Opinion Quarterly 36 (2): 176-187.

Negroponte, Nicholas. 1995. Being Digital. New York: Alfred Knopf.

Peixinho, Ana Teresa. 2011. A Epistolaridade nos Textos de Imprensa de Eça de Queirós [Epistolarity in Eça de Queirós' Press Textes]. Lisboa: FCG/FCT.

Pereira, Henrique Garcia. 2002. Apologia do Hipertexto na deriva do texto [Laudation of Hypertext in Text's Drifts]. Lisboa: Difel.

Ribeiro, Susana Almeida. 2008. Infografia de Imprensa-história e Análise Ibérica Comparada [Press Infographics-History and Compared Iberian Analysis]. Coimbra: Minerva.

Ryan, Marie-Laure. 2001. Narrative as virtual Reality. Immersion and Interactivity in Literature and Electronic Media. London: The Johns Hopkins University Press.

Tarde, Gabriel. 1989. L'Opinion et la Foule [Opinion and the Crowd]. Paris: Presses Universitaires de France.

Thorson, Kjerstin, and Wells Chris. 2015. "How Gatekeeping Still Matters: Understanding Media Effects in an Era of Curated Flows." In Gatekeeping in transition, edited by Tim P. Vos and François Heinderyckx, 25-44. New York, NY: Routledge.

Torres, Marisa. 2010. As cartas dos leitores na imprensa portuguesa: uma forma de comunicação e debate do público [Readers' letters in the Portuguese press: a mean of communication and public debate]. PhD Thesis, Universidade Nova de Lisboa.

Van Dijk, Jan. 2005. The Network Society. Social Aspects of New Media. London: Sage Publication.

Virgil, Johnny. 2007. "A Biblioteca de Babel: uma metáfora da sociedade da informação [Babel's Library: A Metaphor of the Information Society]." [In Portuguese]. In Revista da Ciência da Informação. V. 8, n. 4, agosto, 2007. Accessed February 8, 2015. http://www.dgz.org.br/ago07/Art.04.htm.

Wahl-Jorgensen, Karin. 2002. "The Normative-Economic Justification for Public Discourse: Letters to the Editor as a "Wide-Open" Forum". In: Journalism \& Mass Communication Quarterly, Spring 2002, 79/1: 121-133.

Warner, Michael. 1995. The Letters of the Republic. Publication and the Public Sphere in Eighteenth-Century America, 2nded. Cambridge and London: Harvard University Press.

Clara Almeida Santos (author to whom correspondence should be addressed), Faculdade de Letras, Universidade de Coimbra/Centro de Estudos Interdisciplinares, Portugal. E-mail: clara.santos@uc.pt

Ana Teresa Peixinho, Faculdade de Letras, Universidade de Coimbra/Centro de Estudos Interdisciplinares, Portugal. E-mail: apeixinho71@gmail.com 